\title{
LYMPHOMÁK ADOLESZCENS KORBAN: ÉRDEMES-E GYERMEK-PROTOKOLLAL KEZELNI EZT A BETEGCSOPORTOT?
}

\author{
Bence Zsófia ${ }^{1}$ Kovács Gábor², Jakab Zsuzsanna², Csóka Monika², Müller Judit ${ }^{2}$ \\ Semmelweis Egyetem, ${ }^{1}$ ÁOK, V. évfolyam, ${ }^{2} I I$. sz. Gyermekklinika, Budapest
}

\begin{abstract}
Magyarországon évente 250-300 gyermeknél diagnosztizálnak malignus daganatot. Közülük megközelítöleg minden tizedik lymphomában szenved. Vizsgálatunk célja volt az adoleszcens korú (14-19 éves) Hodgkin- (HL) és non-Hodgkin-lymphomás (NHL) betegek adatainak feldolgozása, túlélési mutatóiknak összehasonlítása a 14 év alattiakéval, illetve a nemzetközi adatokkal. 1990 januárja és 2004 decembere között 281 HL-ban és 230 NHL-ban szenvedő gyermeket kezeltünk és gondoztunk a Magyar Gyermekonkológiai Hálózat központjaiban. A HL-sok közül 107, a NHL-sok közül 51 volt 14 éves kor feletti. A HL-s betegeknél a két korcsoportban hasonló a stádiummegoszlás. A NHL-soknál a 14 évesnél fiatalabbak 55\%-ának, a 14 évnél idősebbek 72\%-ának volt előrehaladott stádiumú (III. vagy IV.) a betegsége. Mindkét betegség esetén a betegek egységes, a gyermekonkológiában elfogadott kemoterápiás protokolloknak megfelelóen kapták a kezelést. A 14 évnél fiatalabb HL-s betegeink teljes túlélése (OS) 5

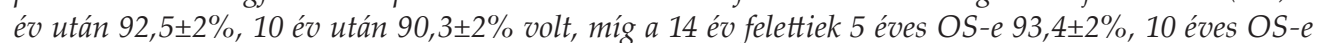

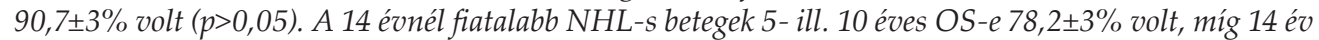

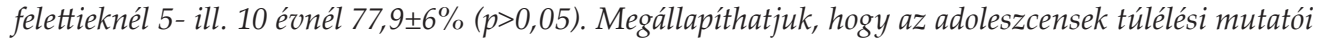
egyik lymphoma-fajtánál sem térnek el szignifikánsan a 14 évnél fiatalabbakétól, ezért az adoleszcens korban fellépö lymphomák kezelésére megfelelóek a gyermekkorban alkalmazott terápiás protokollok. Magyar Onkológia 52: 357-362, 2008
\end{abstract}

Kulcsszavak: Hodgkin-lymphoma, non-Hodgkin-lymphoma, adoleszcens, túlélés, protokoll

The centres of the Hungarian Paediatric Oncology Network annually take care of 250-300 new patients with childhood cancer, every tenth of them suffering from lymphoma. The aim of our work was to analyse the data of the adolescents (14-19 years) with Hodgkin's lymphoma (HL) and non-Hodgkin's lymphoma (NHL), comparing their survival rates with younger patients under fourteen and with the international data. From January 1990 to December 2004 there were 281 children diagnosed with HL and 230 with NHL. Among the HL patients 107, while among the NHL patients 51 were older than 14 years old. In the group of HL the distribution of patients according to the stage was similar in younger and older patients. In the NHL group $55 \%$ of the children younger than 14 , and $72 \%$ of the patients older than 14 years old had advanced stage disease (stage III or IV). In both groups the patients received chemotherapy according to the current paediatric protocols. The overall survival (OS) of the HL patients younger than 14 was $92.5 \pm 2 \%$ at 5 years and $90.3 \pm 2 \%$ at 10 years, and for the adolescents $93.4 \pm 2 \%$ and $90.7 \pm 3 \%$ at 5 and 10 years (n.s.). The OS of the younger children in the NHL group was $78.2 \pm 3 \%$ at 5 and 10 years, and $77.9 \pm 6 \%$ for the adolescents (n.s.). As a conclusion, survival rates of the adolescents do not differ significantly from the parameters of the patients under fourteen, so the therapy protocols used for childhood lymphomas are suitable for the treatment of the lymphomas appearing at the age of 14-19 years. Bence Zs, Kovács G, Jakab Z, Csóka M, Müller J. Lymphomas in adolescents: Are childhood lymphoma therapy protocols suitable for this patient group? Hungarian Oncology 52: 357-362, 2008

Keywords: Hodgkin's lymphoma, non-Hodgkin's lymphoma, adolescent, survival, protocol
Közlésre érkezett: 2008. augusztus 4 .

Elfogadva:

2008. november 7 .

Levelezési cím:

Dr. Müller Judit

Semmelweis Egyetem

II. sz. Gyermekklinika

1094 Budapest

Tüzoltó utca 7-9.

Telefon: (06-1) 215-1380

Fax: (06-1) 215-1381

E-mail:

muller@gyer2.sote.hu

Rövidítések:

6-MP: 6-mercaptopurin;

AFF: adoleszcens-

és fiatal felnőttkor;

ALCL: anaplasztikus

nagy sejtes lymphoma;

Ara-C: cytarabin;

ASP: asparaginase;

B-NHL: B-sejtes NHL;

COPP: cyclophosphamid,

vincristin, procarbazin,

prednisolon;

CP: cyclophosphamid;

DEXA: dexamethason;

DOXO: doxorubicin;

EFS: eseménymentes

túlélés; HL: Hodgkin-

lymphoma; IFO:

ifosfamid; KIR: központi

idegrendszer; LB/T-NHL:

lymphoblastos/

T-sejtes lymphoma; MTX:

methotrexate; NHL:

non-Hodgkin-lymphoma; OEPA: vincristin,

etoposid, prednisolon, adriamycin; OPPA:

vincristin, procarbazin,

prednisolon, adriamycin;

OS: teljes túlélés;

PRED: prednisolon;

PROC: procarbazin;

VCR: vincristin; VDS:

vindesin; VP-16: etoposid 


\section{BEVEZETÉS}

A gyermekkori daganatos betegségek viszonylag ritkák, hazánkban évente 250-300 új beteg kerül a Magyar Gyermekonkológiai Hálózat központjainak gondozásába. A lymphomás esetek ennek mintegy 10-12\%-át teszik ki, évente 25-36 új beteget diagnosztizálunk és kezelünk. Az adoleszcens kor egy egészséges gyermek életében is igen problémás időszak, egy daganatos betegséggel küzdő fiatal esetében ez fokozottan igaz (1).

Vizsgálatunk célja volt a 14-19 év közötti Hodgkinlymphoma (HL) és non-Hodgkin-lymphoma (NHL) miatt Magyarországon kezelt fiatalok klinikai adatainak és túlélési mutatóinak összehasonlítása a 14 év alattiakéval, illetve a nemzetközi eredményekkel való összevetése. Arra kerestük a választ, hogy a hazánkban alkalmazott egységes kemoterápiás protokollok mellett van-e különbség a két korosztály túlélési mutatóiban.

\section{BETEGEK ÉS MÓDSZEREK}

Az Országos Gyermektumor Regiszter adatai szerint 1990 januárja és 2004 szeptembere közötti 281 HL-ban és 230 NHL-ban szenvedő gyermeket kezeltünk és gondoztunk a Magyar Gyermekonkológiai Hálózat központjaiban. A HL-sok közül 174, a NHL-sok közül 179 volt 14 éves kor alatti. 107 HL-s és 51 NHL-s beteg múlt el a diagnózis felállításakor 14 éves. A HL-soknál a fiú:lány arány 14 éves kor alatt 1,48:1, 14 év felett 1:1,38, az átlagéletkor 9 év 10 hónap, illetve 15 év 9 hónap volt.
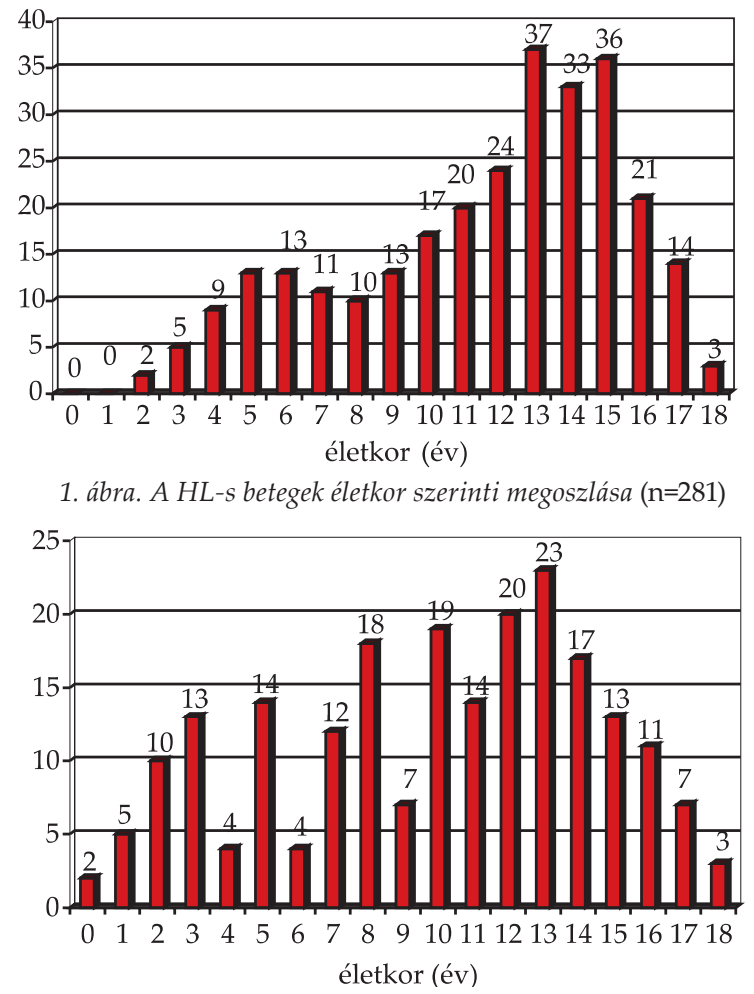

2. ábra. A NHL-s betegek életkor szerinti megoszlása (n=230)
1. táblázat. HL esetén alkalmazott kemoterápiás blokkok

\begin{tabular}{ll}
\hline OPPA-blokk: & VCR, PRED, PROC, DOXO \\
\hline OEPA-blokk: & VCR, VP-16, PRED, DOXO \\
\hline COPP-blokk: & CP, VCR, PRED, PROC \\
\hline
\end{tabular}

CP: cyclophosphamid, DOXO: doxorubicin, PRED: prednisolon, PROC: procarbazin, VCR: vincristin, VP-16: etoposid

A NHL-ban szenvedőknél a fiú:lány arány 14 éves kor alatt 2,5:1, 14 év felett 2,64:1, az átlagéletkor 8 év 5 hónap, illetve 15 év 10 hónap volt. A betegek életkor és lymphomatípus szerinti megoszlását az 1. és 2. ábrán tüntettük fel.

Mindkét betegcsoportban egységesen a Cotswoldi klinikai stádiumbeosztást alkalmaztuk (21).

Mindkét lymphoma-fajtánál a betegek egységes kemoterápiás protokolloknak megfelelő kezelésben részesültek. HL esetén a DAL-HD-90 és a GPOH-HD-95 protokollokat alkalmaztuk (1. táblázat). Mindkét protokollban a lányok két OPPA, a fiúk pedig két OEPA blokkal kezdik kezelésüket. A kiindulási stádiumbesorolásnak, valamint erre a két blokkra adott terápiás válasznak megfelelően folytatódik a kezelés. Az I. és II.a stádiumba sorolt és jó terápiás választ mutató betegek további kemoterápiás kezelésben nem részesültek. A többi beteg további 2 vagy 4 COPP blokkot kapott, illetve szükség esetén a kemoterápia befejezése után sugárkezelésben (RT) részesültek.

NHL esetén a vizsgálati időszak elején az NHLBFM-90, majd 1996-tól az NHL-BFM-95 protokollt használtuk. A különböző biológiai tulajdonságú altípusok eltérően reagálnak a kemoterápiás kezelésre, ezért a betegeket a protokolloknak megfelelően három terápiás csoportba osztottuk be: 1 . lymphoblastos és T-sejtes (LB/T-NHL), 2. B-sejtes (B-NHL) és 3. anaplasztikus nagy sejtes (ALCL) (27). A LB/T-NHL csoportba tartozó betegek kezelése az akut lymphoid leukaemiák kezelésével közel azonos: a kétfázisú indukciós részt rövid terápiás szünet után konszolidációs kezelés követi. A rosszabb prognózisú betegek a konszolidációs kezelést követően reindukciós blokkot kapnak. Minden gyermek részesül per os fenntartó terápiában (26). A B-sejtes csoportba tartozó betegek terápiája egységes: rövid és intenzív kezelés (5-6 napos, több citosztatikum kombinációjából álló blokkok), melyet nem követ fenntartó kezelés. Ezen a csoporton belül négy rizikócsoportot különböztetünk meg: a tumorszövet reszekciója mértékének, a betegség stádiumbesorolásának, valamint a kezdeti LDH-szintnek megfelelően. A rizikócsoportoktól függ a blokkok száma és hossza (2-6 blokk) (28). Az ALCL-s betegeken belül a lymphoma kiterjedésének megfelelően három alcsoportot különböztetünk meg és a kezelés a B-NHL kezelésénél alkalmazott blokk-kezeléshez hasonló (29). Mindhárom terápiás csoportba tartozó beteg részesül központi idegrendszeri profilaxisban (intratekális citosztatikum- és irradiációs kezelés). Az alkalmazott két protokoll közötti különbség az egyes kemoterápiás gyógyszerek adagjaiban, illetve a terápiás csoporton belüli rizikócsoportba való besorolásban 
2. táblázat. A három terápiás csoport kezelése során alkalmazott orális és parenterális gyógyszer-kombinációk

\begin{tabular}{ll}
\hline 1. terápiás csoport & \\
\hline Indukció: & $\mathrm{PRED}, \mathrm{VCR}, \mathrm{ASP}, \mathrm{DNR}, \mathrm{CP}$, Ara-C, 6-MP \\
Konszolidáció & $\mathrm{MTX}, 6-\mathrm{MP}$ \\
Reindukció: & $\mathrm{DEXA}, \mathrm{VCR}, \mathrm{ASP}, \mathrm{DOXO}, \mathrm{CP}$, Ara-C, TG \\
Fenntartó: & 6-MP, MTX
\end{tabular}

2. terápiás csoport

\begin{tabular}{ll}
\hline A-blokk: & DEXA, VCR, MTX, IFO), Ara-C, VP-16 \\
B-blokk: & DEXA, VCR, MTX, CP, DOXO \\
AA-blokk: & DEXA, VCR, MTX, IFO, Ara-C, VP-16 \\
BB-blokk: & DEXA, VCR, MTX, CP, DOXO \\
CC-blokk: & DEXA, VDS, Ara-C, VP-16 \\
\hline
\end{tabular}

3. terápiás csoport

\begin{tabular}{ll}
\hline A-blokk: & DEXA, VCR, MTX, IFO, Ara-C, VP-16 \\
B-blokk: & DEXA, VCR, MTX, CP, DOXO \\
AA-blokk: & DEXA, VCR, MTX, IFO, Ara-C, VP-16 \\
BB-blokk: & DEXA, VCR, MTX, CP, DOXO \\
CC-blokk: & DEXA, VDS, Ara-C, VP-16 \\
\hline
\end{tabular}

6-MP: 6-mercaptopurin, Ara-C: cytarabin, ASP: asparaginase, CP: cyclophosphamid, DEXA: dexamethason, DOXO: doxorubicin, DNR: daunorubicin; IFO: ifosphamid, MTX: methotrexate; TG: thioguanin; VCR: vincristin, VDS: vindesin, VP-16: etoposid

volt. A három terápiás csoportnál alkalmazott orális és parenterális gyógyszerek kombinációit a 2. táblázatban foglaltuk össze.

A teljes túlélést (OS) a kemoterápiás kezelés első napja és a legutolsó kontroll vagy a halál bekövetkeztének dátuma között eltelt időből számoltuk. Az eseménymentes túlélés (EFS) a kezelés első napja és valamely esemény (exitus, alapbetegség relapszusa, második tumor) bekövetkezte között eltelt idő. A statisztikai számításokhoz az SPSS 10.0 számítógépes programot használtuk. A kumulatív túlélési valószínűséget a Kaplan-Meier-módszer szerint határoztuk meg. Az egyes betegcsoportok túlélése közötti különbségek vizsgálata log-rank-teszttel történt. A szövettani alcsoportok és stádiumbeosztás szerinti összehasonlításra Fisher-próbát használtunk. A p<0,05 valószínűségi szintet tekintettük szignifikánsnak.

\section{EREDMÉNYEK}

A betegek stádium szerinti beosztását a 3. és 4. táblázatokban tüntettük fel. A HL-s betegeknél a két korcsoport stádiummegoszlása között nincsen szignifikáns különbség. Azonban említésre méltó, hogy a NHL-sok közül az adoleszcens korúaknál a betegek több mint 70\%-a előrehaladott stádiumban (III. és IV.) kerül felismerésre és a 14 alattiaknál is 50\% felett van ez az arány.
3. táblázat. A HL-s betegek ( $\mathrm{n}=281)$ megoszlása stádium és korcsoportok szerint

\begin{tabular}{cccc}
\hline Stádium & $\begin{array}{c}<14 \text { év } \\
(\mathrm{n}=174)\end{array}$ & $\begin{array}{c}>14 \text { év } \\
(\mathrm{n}=107)\end{array}$ & $\mathrm{p}$ \\
\hline I. & $33 / 174 ; 19 \%$ & $12 / 107 ; 11 \%$ & 0,096 \\
II. & $80 / 174 ; 46 \%$ & $50 / 107 ; 47 \%$ & 0,537 \\
III. & $60 / 174 ; 34,5 \%$ & $37 / 107 ; 35 \%$ & 0,547 \\
IV. & $1 / 174 ; 0,5 \%$ & $8 / 107 ; 7 \%$ & 0,006 \\
\hline
\end{tabular}

4. táblázat. A NHL-s betegek $(\mathrm{n}=230)$ megoszlása stádium és korcsoportok szerint

\begin{tabular}{cccc}
\hline Stádium & $\begin{array}{c}<14 \text { év } \\
(\mathrm{n}=179)\end{array}$ & $\begin{array}{c}>14 \text { év } \\
(\mathrm{n}=51)\end{array}$ & $\mathrm{p}$ \\
\hline I. & $24 / 179 ; 13 \%$ & $4 / 51 ; 8 \%$ & 0,463 \\
II. & $55 / 179 ; 31 \%$ & $10 / 51 ; 20 \%$ & 0,077 \\
III. & $63 / 179 ; 35 \%$ & $29 / 51 ; 57 \%$ & 0,005 \\
IV. & $37 / 179 ; 20 \%$ & $8 / 51 ; 15 \%$ & 0,006 \\
\hline
\end{tabular}

5. táblázat. A HL-s betegek $(\mathrm{n}=281)$ megoszlása szövettani besorolás és korcsoportok szerint

\begin{tabular}{lrcc}
\hline \multicolumn{1}{c}{ Szövettani alcsoport } & $\begin{array}{c}<14 \text { év } \\
(\mathrm{n}=174)\end{array}$ & $\begin{array}{c}>14 \text { év } \\
(\mathrm{n}=107)\end{array}$ & $\mathrm{p}$ \\
\hline nodularis sclerosis & $60 / 174 ; 34 \%$ & $63 / 107 ; 59 \%$ & 0,000 \\
kevert sejtes & $64 / 174 ; 37 \%$ & $27 / 107 ; 25 \%$ & 0,000 \\
$\begin{array}{l}\text { lymphocyta-predomi- } \\
\text { nancia }\end{array}$ & $33 / 174 ; 19 \%$ & $11 / 107 ; 10 \%$ & 0,045 \\
$\begin{array}{l}\text { lymphocyta-depletio } \\
\text { nodularis lymphocyta- }\end{array}$ & $7 / 174 ; 4 \%$ & $1 / 107 ; 1 \%$ & 0,161 \\
predom. & $0 / 174 ; 0 \%$ & $3 / 107 ; 3 \%$ & 0,054 \\
nem besorolható & $10 / 174 ; 6 \%$ & $2 / 107 ; 2 \%$ & 0,015 \\
\hline
\end{tabular}

6. táblázat. A NHL-s betegek $(\mathrm{n}=230)$ megoszlása terápiás alcsoportok és korcsoportok szerint

$$
\text { Szövettani alcsoport }
$$$$
<14 \text { év }
$$$$
(\mathrm{n}=179)
$$

$>14$ év $(\mathrm{n}=51)$

$\mathrm{p}$

1. terápiás csoport

(lymphoblastos lympho-

mák, T-sejtes lymphomák) 76/179; 42\% 15/51; 29\%

2. terápiás csoport

(B-sejtes lymphomák

Burkitt-, Burkitt-like

lymphoma)

$82 / 179 ; 46 \% \quad 26 / 51 ; 51 \%$

0,635

3. terápiás csoport

(anaplasztikus nagysejtes

lymphomák)

$21 / 179 ; 12 \% \quad 10 / 51 ; 20 \%$

0,159

A HL-sok szövettani altípusok szerinti besorolása az 5. táblázatban látható. Mindkét korcsoportban a leggyakoribb a nodularis sclerosis, míg második leggyakoribb a kevert sejtes forma. A két csoport között kiemelendő különbség, hogy az adoleszcenseknél több a nodularis sclerosis és kevesebb a lymphocyta-predominancia forma. A NHL szövettani fajtáit három csoportba soroltuk be (6. táblázat), melyek megfelelnek a BFM protokollok terápiás csoportjainak. Mindkét korosztálynál a betegek közel fele a 2. terápiás csoportba volt besorol- 
ható. Ebbe a csoportba 108 beteg tartozott, döntő többségüknek Burkitt- vagy Burkitt-like lymphomája volt. Ugyancsak ebbe a csoportba tartoztak a diffúz nagy B-sejtes lymphomás betegek (12/108), és ennek a terápiás csoportnak megfelelő kezelést kaptak. Follicularis lymphomát betegeink között nem észleltünk.

A 281 HL-s beteg közül 256-an jelenleg is komplett remisszióban vannak 6 év követési idő után. A 14 év alattiak közül 16 (16/174; 9,2\%), a 14 éves kor felettiek közül 9 (9/107; 8,4\%) gyermeket veszítettünk el. A 230 NHL-s betegből jelenleg 179 komplett remisszióban van átlagosan 6 év követési idő után. A 14 év alattiak közül 39 (39/179; 21,8\%), a 14 éves kor felettiek közül 11 (11/51; $21,6 \%)$ gyermeket veszítettünk el.

A 14 éves kor alatti HL-s betegek 9,2\%-ában (16/174), a 14 éves kor felettiek 13\%-ában (14/107) észleltük az alapbetegség relapszusát. A NHL-soknál a 14 évnél fiatalabbaknál 11,7\% (21/179), a 14 évnél idősebbeknél 13,7\% (7/51) volt a relapszus aránya. A diagnózis felállítása és a relapszus között eltelt idő az előbbi csoportban 14,5 (1,3-85,7), míg az utóbbiban 8,1 (0,5-23) hónap volt.

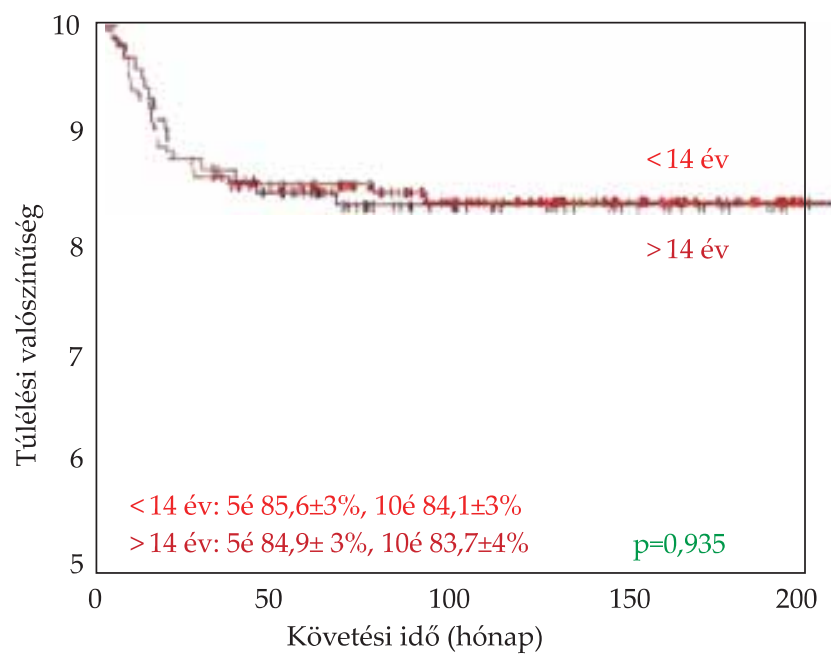

3. ábra. A HL-s betegek ( $\mathrm{n}=281)$ eseménymentes túlélése (EFS) életkor szerint

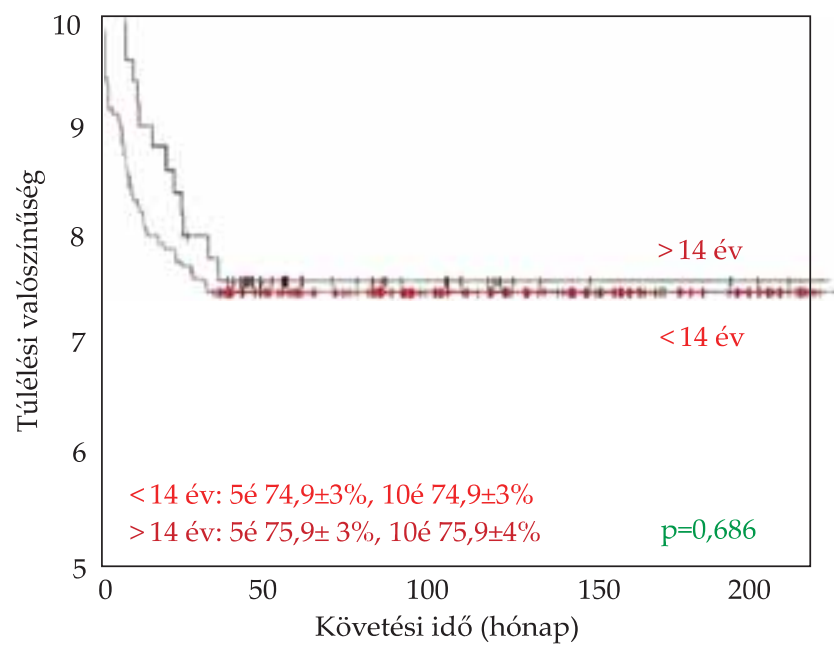

4. ábra. A NHL-s betegek $(\mathrm{n}=230)$ eseménymentes túlélése (EFS) életkor szerint
A 14 évnél fiatalabb HL-s betegeink OS-e 5 évnél $92,5 \pm 2 \%$, 10 évnél $90,3 \pm 2 \%$, míg a 14 év felettieké 5 évnél $93,4 \pm 2 \%, 10$ évnél 90,7 $73 \%$ volt $(p=0,866)$. A 14 évesnél fiatalabb HL-sok EFS-e 85,6 $\pm 3 \%$ volt 5 évnél és $84,1 \pm 3 \% 10$ évnél. Ugyanezen időpontokban a 14 évesnél idősebbek ESF-e $84,9 \pm 3 \%$ és $83,7 \pm 4 \%$ volt $(p=0,727)$ (3. ábra).

A 14 évnél fiatalabb NHL-s betegeink OS-e 5 és 10 évnél $78,2 \pm 3 \%$, míg a 14 évet betöltötteké $77,9 \pm 6 \%$ volt $(\mathrm{p}=0,885)$. A EFS a 14 év alattiaknál 5 és 10 évnél is $74,9 \pm 3 \%$, míg a 14 évesnél idősebbeknél $75,9 \pm 6 \%$ volt $(\mathrm{p}=0686)$ (4. ábra).

\section{MEGBESZÉLÉS}

A gyermekkorban fellépő daganatok kezelésének célja a tumorsejtek teljes eradikációja és a teljes gyógyulás elősegítése, azonban minden esetben szem előtt kell tartani hosszú távon az életminőség megőrzését, a késői mellékhatások minimalizálását. Az adoleszcens korú betegek életüknek különösen érzékeny periódusában vannak, hiszen a növekedés sebessége az első életév után éppen ezekben az években a legintenzívebb, a szervek kemoterápiás szerekre való érzékenysége különösen nagy körültekintésre inti a kezelőorvost (12). Emellett nem elhanyagolható a pszichológiai komponens sem, ami ennek a korosztálynak a gyógyulását igen jelentős mértékben befolyásolja. Az utóbbi időben egyre nagyobb figyelmet fordítanak a gyermekonkológiai központok az adoleszcens- és fiatal felnőttkorban (AFF) lévő betegek ellátására, mivel az adoleszcens korú daganatos betegek kiemelt kockázatú csoportnak számítanak (10, 12, 13).

A gyermekonkológiai megbetegedések túlélési mutatói tovább emelkedtek az utóbbi évtizedekben, és a kemoterápiás kezelések akut és késői mellékhatásainak vizsgálatára is több figyelem fordult. Infertilitás, második daganat megjelenése, szív-, tüdő- és endokrinológiai problémák továbbra is gyakori szövődményei a kombinált kezeléseknek, különösen az AFF betegeknél $(20,32)$. Ezért ebben a betegcsoportban a kemoterápia megválasztásánál az említett szempontokat is figyelembe vesszük $(16,17,23)$.

Az AFF-ban jelentkező daganatos betegségek száma világszerte alacsony, incidenciája 15-24 éves kor között 200/1 millió fő; ezzel az összes tumoros megbetegedés kevesebb mint 0,5\%-át teszik ki (11). Az AFF-ban fellépő tumorok megoszlása jelentősen eltér mind a fiatal gyermekkorban, mind a felnőttkorban gyakori daganatok megoszlásától. Míg gyermekkorban a leukaemiák (27\%), központi idegrendszeri tumorok (KIR) (25\%) és lymphomák (12\%) a leggyakoribb onkológiai kórképek, addig az AFF-ban első helyen a lymphomák állnak (HL: 16\%, NHL: 10\%), megelőzve a leukaemiákat és a KIR tumorokat (12\% és 10\%) (3). Az ACCIS (Automated Childhood Cancer Information System) adatbázis 1978 és 1997 közötti adatai azt mutatják, hogy az adoleszcens kori non-Hodgkin-lymphoma incidenciája évente 1,7\%kal növekszik (14). 
Az AFF-ben fellépő összes daganatos megbetegedés 5 éves túlélése Európában átlagosan 73\%, az USA-ban $78 \%$ (7). Levi és munkatársainak vizsgálata azt mutatta ki, hogy 1965 és 1998 között világszerte nagyjából 40\%kal csökkent az adoleszcens kori tumorok össz-mortalitása (18).

Mivel egyes lymphomatípusok biológiai viselkedése az életkor folyamán változik, további széles körü vizsgálatok szükségesek annak eldöntésére, hogy a különböző életkorú betegek milyen kemoterápiát kapjanak (24).

A SEER (Surveillance, Epidemiology and End Results) felmérés szerint a 15-19 éves korosztályon belül a HL túlélése az 1975-1984 közötti 88\%-ról 1985-1994 között 90\%-ra emelkedett, míg az NHL túlélése ugyanezen két periódusban $56 \%$, illetve $69 \%$ volt $(30,33)$. Az Amerikai Egyesült Államokban készített felmérés szerint 1981-2004 között 259 adoleszcens korú HL-s beteg OS-e 5 évnél 94\%, 10 évnél 91\% volt (9). Gatta és Desandes 1990-1994 közötti vizsgálatában ugyancsak európai 15-24 éves HL-sok 5 éves túlélése 89\% volt, míg a NHLsoké $68 \%(7,11)$.

A gyermekkori HL hazai kezelési eredményeit pár évvel ezelőtt mutattuk be (15). Az 1988-1998 közötti időszakban a 0-15 éves korosztály OS-e 5 évnél 95\%, 10 évnél 92\% volt. A NHL-val szerezett itthoni tapasztalataink szerint a magyar gyermekek túlélési mutatói nem térnek el lényegesen a nemzetközi adatoktól (19). Az 1990-2004 közötti időszakban a NHL-BFM protokollokkal kezelt 0-18 éves NHL-ban szenvedő gyermekek OS-e 5 évnél $78 \%$ volt.

Jelen munkánk során mindkét megbetegedés esetén a betegeket két csoportba osztottuk, 14 éves kor alatti és feletti életkorúakra. A HL-soknál nem volt lényegi különbség a stádiumbesorolásnál a két korcsoport között, a 14 évesnél idősebbeknél szignifikánsan több volt a IV. stádiumú betegség. Figyelemre méltó, hogy NHL esetén mindkét csoportban a betegek több mint felénél (<14 év: 55\%,>14 év: 72\%) előrehaladott stádiumban (III. vagy IV.) volt a betegség a diagnózis felállításakor, és e különbségek szignifikáns eltérések. Hangsúlyoznunk kell, hogy a daganatos betegségek korai felismerése javítja a túlélést, mivel egy alacsonyabb stádiumú betegség prognózisa mindig jobb az előrehaladott stádiumúénál. HL-n belül, idősebb korban a nodularis sclerosis szövettani forma volt a leggyakoribb, míg a 14 év alattiaknál a kevert sejtes típus. Említésre méltó, hogy a kedvezőtlen prognózist mutató lymphocyta-depléciós forma mindkét korcsoportban ritkán fordult elő (4\%, illetve 1\%). NHL-n belül mindkét korcsoportban a betegek közel fele a BFM munkacsoport által meghatározott B-sejtes csoportba tartozott, mely a nemzetközi adatoknak megfelel (5). A két betegcsoport között nem volt szignifikáns különbség a terápiás alcsoportok között. Sem az OS-nél, sem a EFS-nél nem találtunk statisztikailag szignifikáns eltérést egyik betegség esetén sem a 14 éves kor alatti és feletti betegek összehasonlítása során. A HL 5 éves OS-e mindkét korcsoportban meghaladta a 90\%-ot, míg NHL esetén az 5 éves OS közel $78 \%$ volt mindkét csoportban.
A nemzetközi tapasztalatok eltérőek az adoleszcens korú lymphomás betegek kezelésével, míg egyes központokban a gyermekonkológusok, addig más központokban a felnőttek esetében használatos protokollok szerint kezelik a AFF betegeket (31). Több országban összehasonlították az adoleszcens korú akut lymphoid leukaemiások túlélési eredményeit kezelési protokoll szerint, és egyértelmüen bizonyítható volt, hogy gyermek-protokollokkal a túlélési mutatók szignifikánsan jobbak a felnőtt-protokollal kezelteknél $(4,6,25)$. Rhabdomyosarcoma és Ewing-sarcoma esetében is a leukaemiához hasonlóan, a felnőtt-protokollal kezelt adoleszcensek túlélése rosszabbnak bizonyult $(8,22)$.

Összefoglalásul megállapíthatjuk, hogy az adoleszcens korú lymphomás betegek hazai túlélési eredményei a nemzetközi adatoknak megfelelnek. Mindkét lymphomatípusnál a betegek életkoruktól függetlenül a gyermekkorban alkalmazandó kezelési protokollnak megfelelően kapták kezelésüket. Mivel a túlélési eredmények között nincsen szignifikáns különbség, hangsúlyozzuk, hogy az adoleszcens betegek esetében sikeresen alkalmazhatóak a gyermekkori kezelési protokollok.

\section{KÖSZÖNETNYILVÁNÍTÁS}

Ezúton szeretnénk köszönetet mondani Dr. Ponyi Andreának a statisztikai számítások elvégzésében nyújtott segítségéért, illetve a Magyar Gyermekonkológiai Hálózat munkatársainak az aktív együttműködésért (a központok vezetői a fenti időperiódusban: Koós R., Bp., SE II. sz. Gyermekklinika; Rényi I., Bp., SE I.sz. Gyermekklinika; Magyarosy E., Bp., Heim Pál Kh.; Galántai I., Bp., Madarász u. Kh.; Békési A., Bp., Bethesda Kh.; Kajtár P., Pécs, Pécsi Tudományegyetem Gyermekklinika; Kiss Cs., Debrecen, Debreceni Tudományegyetem Gyermekklinika; Nagy K., Miskolc, BAZ Megyei Kórház Gyermekosztálya; Bartyik K., Szeged, Szegedi Tudományegyetem Gyermekklinika; Masáth P., Szombathely, Markusovszky Kórház Gyermekosztálya; Kriván G., Bp., Szent László Kórház).

\section{IRODALOM}

1. Albritton K, Bleyer WA. The management of cancer in the older adolescent. Eur J Cancer 39:2584-2599, 2003

2. Bleyer A, Budd T, Montello M. Adolescents and young adults with cancer: the scope of the problem and criticality of clinical trials. Cancer 107:1645-1655, 2006

3. Bleyer A, Viny A, Barr R. Cancer in 15- to 29-year-olds by primary site. Oncologist 11:590-601, 2006

4. Boissel N, Auclerc MF, Lheritier V, et al. Should adolescents with acute lymphoblastic leukemia be treated as old children or young adults? Comparison of the French FRALLE-93 and LALA-94 trials. J Clin Oncol 21:774-780, 2003

5. Burkhardt B, Zimmermann M, Oschlies I, et al. The impact of age and gender on biology, clinical features and treatment outcome of non-Hodgkin lymphoma in childhood and adolescence. Br J Haematol 131:39-49, 2005

6. de Bont JM, Holt B, Dekker AW, et al. Significant difference in outcome for adolescents with acute lymphoblastic leukemia treated on 
pediatric vs adult protocols in the Netherlands. Leukemia 18:20322035, 2004

7. Desandes E. Survival from adolescent cancer. Cancer Treat Rev 33:609-615, 2007

8. Ferrari A, Dileo P, Casanova M, et al. Rhabdomyosarcoma in adults. A retrospective analysis of 171 patients treated at a single institution. Cancer 98:571-580, 2003

9. Foltz LM, Song KW, Connors JM. Hodgkin's lymphoma in adolescents. J Clin Oncol 24:2520-2526, 2006

10. Freyer DR, Brugieres L. Adolescent and young adult oncology: transition of care. Pediatr Blood Cancer 50:1116-1169, 2008

11. Gatta G, Capocaccia R, De Angelis R, et al. Cancer survival in European adolescents and young adults. Eur J Cancer 39:2600-2610, 2003

12. Herbertson R, Hancock BW. Hodgkin lymphoma in adolescents. Cancer Treat Rev 31:339-360, 2005

13. Hollis R, Morgan S. The adolescent with cancer--at the edge of noman's land. Lancet Oncol 2:43-48, 2001

14. Izarzugaza MI, Steliarova-Foucher E, Martos MC, et al. Non-Hodgkin's lymphoma incidence and survival in European children and adolescents (1978-1997): report from the Automated Childhood Cancer Information System project. Eur J Cancer 42:2050-2063, 2006

15. Kovács G, Müller J, Borgulya G, et al. A gyermekkori Hodgkinlymphoma kezelési eredményei Magyarországon. Magyar Onkológia 45:397-401, 2001

16. Kovacs GT, Barany O, Schlick B, et al. Late immune recovery in children treated for malignant diseases. Pathol Oncol Res, 2008, PMID: 18575827

17. Kovacs GT, Erlaky H, Toth K, et al. Subacute cardiotoxicity caused by anthracycline therapy in children: can dexrazoxane prevent this effect? Eur J Pediatr 166:1187-1188, 2007

18. Levi F, Lucchini F, Negri E, et al. Trends in cancer mortality at age 15 to 24 years in Europe. Eur J Cancer 39:2611-2621, 2003

19. Muller J, Csoka M, Jakab Z, et al. Treatment of pediatric non-Hodgkin lymphoma in Hungary: 15 years experience with NHL-BFM 90 and 95 protocols. Pediatr Blood Cancer 50:633-635, 2008

20. Oeffinger KC, Eshelman DA, Tomlinson GE, et al. Providing primary care for long-term survivors of childhood acute lymphoblastic leukemia. J Fam Pract 49:1133-1146, 2000

21. Olweny CL. Cotswolds modification of the Ann Arbor staging system for Hodgkin's disease. J Clin Oncol 8:1598, 1990

22. Paulussen S, Ahrens S, Jürgens HF. Cure rates in Ewing tumor patients aged over 15 years are better in pediatric oncology units.
Results of GPOH CESS/EICESS studies. Proc Am Soc Clin Oncol 22:816, 2003

23. Pentheroudakis G, Pavlidis N. Late toxicity in survivors from adolescent cancers. Cancer Treat Rev 33:656-663, 2007

24. Perkins SL, Lones MA, Davenport V, et al. B-Cell non-Hodgkin's lymphoma in children and adolescents: surface antigen expression and clinical implications for future targeted bioimmune therapy: a children's cancer group report. Clin Adv Hematol Oncol 1:314-317, 2003

25. Ramanujachar R, Richards S, Hann I, et al. Adolescents with acute lymphoblastic leukaemia: outcome on UK national paediatric (ALL97) and adult (UKALLXII/E2993) trials. Pediatr Blood Cancer 48:254-261, 2007

26. Reiter A, Schrappe M, Ludwig WD, et al. Intensive ALL-type therapy without local radiotherapy provides a 90\% event-free survival for children with T-cell lymphoblastic lymphoma: a BFM group report. Blood 95:416-421, 2000

27. Reiter A, Schrappe M, Parwaresch R, et al. Non-Hodgkin's lymphomas of childhood and adolescence: results of a treatment stratified for biologic subtypes and stage--a report of the BerlinFrankfurt-Munster Group. J Clin Oncol 13:359-372, 1995

28. Reiter A, Schrappe M, Tiemann M, et al. Improved treatment results in childhood B-cell neoplasms with tailored intensification of therapy: A report of the Berlin-Frankfurt-Munster Group Trial NHL-BFM 90. Blood 94:3294-306, 1999

29. Reiter A, Schrappe M, Tiemann M, et al. Successful treatment strategy for Ki-1 anaplastic large-cell lymphoma of childhood: a prospective analysis of 62 patients enrolled in three consecutive Berlin-Frankfurt-Munster group studies. J Clin Oncol 12:899-908, 1994

30. Ries LAG, Eisner MP Kosary CL et al. SEER caner statistics review, 1973-1998. Bethesda, MD: National Cancer Institute 2001. http:// seer.cancer.gov/publications/CSR1973_1998/505

31. Sandlund JT. Should adolescents with NHL be treated as old children or young adults? Hematology Am Soc Hematol Educ Program 2007:297-303, 2007

32. Schwartz CL. Health status of adult long-term survivors of childhood cancer: a report from the Childhood Cancer Survivor Study. J Pediatr 144:407-408, 2004

33. Smith MA, Gurney JG, Ries LAG. Cancer in adolescents 15-19 years old. In: Cancer Incidence and Survival among Children and Adolescents: United States SEER Program 1975-1997. Eds: Ries LAG, Smith MA, Gurney JG et al. Bethesda, MD: National Cancer Institute, SEER Program 1999; NIH Publ no 99-4649 